Black, D. A. K., and Moore, T. (1969). Geriatrics, 24, No. 2, p. 126. British Medical fournal, 1967, 1, 581.

Cameron, J. S., et al. (1970). Proceedings of the European Dialysis and Transplant Association, 7. In press.

Cohen, S. L., Comty, C. M., and Shapiro, F. L. (1970). Proceedings of the European Dialysis and Transplant Association, 7. In press.

Davies, D. F., and Shock, N. W. (1950). Fournal of Clinical Investigation,

29, 496.
de Wardener, H. E. (1966). In Ethics in Medical Progress, ed. G. E. W.

Wolstenholme and M. O'Connor, P. 104. London, Churchill.

Heider, C. H., and Brest, A. N. (1963). Geriatrics, 18, No. 6, p. 489
Lapides, J., and Zierdt, D. (1967). Fournal of the American Medical Association, 201, 778.

Lewis, W. H., and Alving, A. S. (1938). American fournal of Physiology, 123,500 .

Morrin, P. A. (1966). Canadian Medical Association fournal, 94, 1353.

Oliver, J. R. (1952). In Cowdry's Problems of Ageing, 3rd edn., ed. A. I. W Lansing, p. 631. Baltimore, Williams and Wilkins.

Sheil, A. G. R., et al. (1969). Lancet, 2, 917.

Thaysen, J. H. (1966). Proceedings of the European Dialysis and Transplant Association, 3, 138 .

\title{
Use of Oxprenolol in Cardiac Arrhythmias Associated with Acute Myocardial Ischaemia
}

\author{
G. SANDLER, A. C. PISTEVOS
}

British Medical fournal, 1971, 1, 254-257

\section{Summary}

Oxprenolol, a new beta-receptor blocking drug with intrinsic sympathomimetic activity, was used to treat 63 episodes of cardiac arrhythmia occurring in 43 patients with acute myocardial infarction or myocardial ischaemia. The drug was most effective in abolishing ventricular ectopic beats and supraventricular tachycardia. The best method of administration was by continuous intravenous infusion and the most satisfactory bolus dose was $6 \mathrm{mg}$. The main side effect was hypotension, which occurred in $59 \%$ of episodes of arrhythmia that had responded previously to intravenous administration. Oxprenolol was often effective in lignocaine-resistant arrhythmia. The two main advantages of oxprenolol over propranolol are the reduced likelihood of adversely affecting myocardial function and the diminished tendency to produce bronchospasm.

\section{Introduction}

Since the introduction of beta-adrenergic blocking drugs in cardiac arrhythmias by Stock and Dale in 1963 these drugs have been used extensively to treat a variety of arrhythmias associated both with acute myocardial infarction and with chronic heart disease (Harrison et al., 1965; Bath, 1966; Epstein and Braunwald, 1966; Frieden et al., 1967; Irons et al., 1967; Theilen and Wilson, 1968). There are, however, two main disadvantages associated with the use of these drugs: firstly, a deleterious effect on myocardial function (Chamberlain, 1966; Stephen, 1966); and, secondly, an adverse effect on the bronchial musculature leading to bronchospasm (McNeill, 1964; Sandler and Clayton, 1970). Oxprenolol is a new beta-adrenergic blocking agent which is equipotent with propranolol in its negative chronotropic action, but is claimed to produce significantly less depression of myocardial contractility (Grandjean and Rivier, 1968). Preliminary observations have suggested that the antiarrhythmic action of oxprenolol is as effective as that of propranolol (Waal, 1968), but the assessment was based on oral therapy mainly in outpatients with arrhythmias associated with chronic heart disease. In view of the potential value of oxprenolol in treating acute

Coronary Care Unit, St. Helen Hospital, Barnsley G. SANDLER, M.D., M.R.C.P., Consultant Physician A. C. PISTEVOS, M.D., Senior House Officer arrhythmias after myocardial infarction, it was decided to investigate the use of parenteral therapy with oxprenolol in this situation.

\section{Patients and Methods}

Forty-three patients aged 39 to 74 years were studied after admission to the coronary care unit. Thirty-four had typical QS and/or sequential S-T changes in the electrocardiogram $\vec{\theta}$ associated with raised serum enzymes (aspartate aminotransferase and lactate dehydrogenase), confirming acute myocardial infarction. This was anterior in 24 , inferior in eight, and high lateral in two. Three patients had classical ischaemic pain, with left bundle-branch block on the electrocardiogram $\overline{0}$ in one and raised serum enzymes without E.C.G. changes in the other two. Five patients had ischaemic cardiac pain but $\varrho$ no E.C.G. or enzyme changes, and one patient was admitted $\overrightarrow{\hat{O}}$ for a pulmonary embolus. Some of the patients had more 3 than one episode of arrhythmia, so that the total number of $F$ attacks of arrhythmia treated was 63.

All patients were monitored continuously on an oscilloscope, and tracings were obtainable on a direct-writing recorder linked with the oscilloscope. Electrocardiographic records were taken before and at frequent intervals (usually 3 . every 30 seconds) after administration of oxprenolol. Particu- $\delta$ lar attention was also paid to the effects of the drug on the blood pressure, and other side effects were also carefully 0 noted.

Patients with bronchial asthma, heart failure, atrioven- $\mathcal{N}$ tricular block, and bradycardia were excluded from the trial. I

The acute effects of oxprenolol on the arrhythmias were studied by single intravenous bolus injections of the drug in $N$ various doses and also by means of continuous intravenous $\underset{\omega}{N}$ infusion. The bolus injection was given initially in a dose of 20 $\mathrm{mg}$, and if this was not effective within 10 minutes a further 0 injection of $4 \mathrm{mg}$ was given. If no effect was obtained after a further 10 minutes a final bolus of $6 \mathrm{mg}$ was given provided $\stackrel{\mathscr{?}}{+}$ that no significant hypotensive or other adverse side effects $\square$ appeared. The continuous intravenous infusion was given by electrically driven syringe pump, using $30 \mathrm{mg}$ of oxprenolol $\stackrel{\Phi}{\Phi}$ mixed with $30 \mathrm{ml}$ of sterile water $B P$., and the infusion rate $\stackrel{\mathbb{Q}}{\Omega}$ was adjusted to deliver oxprenolol in a dose of 0.250 $\mathrm{mg} / \mathrm{minute}$. The infusion was continued until suppression of the arrhythmia or until the total dose was delivered over a 0 period of two hours. In addition to the intravenous study, the effect of oral oxprenolol in a dose of 20 to $40 \mathrm{mg}$ six-hourly was assessed in a number of patients as a prophylactic measure.

The types of arrhythmia studied included supraventricular 
tachycardia (the atrial rate exceeding 120/minute), supraventricular ectopic beats (atrial and nodal) occurring more frequently than once every 10 normal beats, atrial fibrillation, ventricular ectopic beats (unifocal exceeding 1 in 10 normal beats, multifocal of any frequency, and especially R-on-T), and ventricuar tachycardia. Oral oxprenolol was given to patients who had previously responded successfully to intravenous administration but had developed a recurrence of a similar arrhythmia within several hours.

\section{Results}

Supraventricular Tachycardia.-The effectiveness of the control achieved by oxprenolol, based on the final heart rate, has been related to the initial heart rate (Table I). Thirteen out of 27 episodes can be regarded as attaining good control with oxprenolol, the heart rate dropping to below $100 /$ minute. Less satisfactory control was obtained in a further seven episodes in which the average fall in heart rate was $24 /$ minute and the final rate achieved was 100-109/minute. Though the average fall in heart rate in the remaining seven episodes was $33 /$ minute, the final rate was unsatisfactory, over $110 /$ minute. The results show that successful control with oxprenolol seems to be inversely related to the rapidity of the initial heart rate.

Supraventricular Ectopics, Atrial Fibrillation.-Only two out of six episodes of supraventricular ectopics were abolished by oxprenolol (Table II). None of the seven episodes of atrial fibrillation reverted to sinus rhythm, and in only three of the seven did oxprenolol result in a fall of the ventricular rate to below $100 /$ minute.

Ventricular Arrhythmia.-Oxprenolol abolished ventricular ectopic beats in 13 out of 18 episodes (72\%), and also restored sinus rhythm in two out of three patients with idioventricular rhythm. The remaining episode of idioventricular rhythm responded to oxprenolol with a reduced ventricular rate, but reversion to sinus rhythm occurred only some some hours later during maintenance therapy with oral oxprenolol, $20 \mathrm{mg}$ four times a day. Results of oxprenolol treatment of two episodes of ventricular tachycardia were less satisfactory. In one episode the intravenous injection of $2 \mathrm{mg}$ was followed by a severe hypotensive reaction and within a few minutes ventricular fibrillation developed which fortunately responded to cardioversion. The second patient was already having intravenous infusion of lignocaine $4 \mathrm{mg} / \mathrm{minute}$ and oral procainamide, and when given $2 \mathrm{mg}$ of oxprenolol intra-

TABLE I-Effect of Oxprenolol in Supraventricular Tachycardia

\begin{tabular}{|c|c|c|c|c|c|}
\hline \multicolumn{2}{|c|}{ Results of Treatment } & \multirow{2}{*}{$\begin{array}{c}\text { Average } \\
\text { Pretreatment } \\
\text { Heart Rate } / \text { min }\end{array}$} & \multirow[b]{2}{*}{$\begin{array}{c}\text { Average Fall } \\
\text { in Heart } \\
\text { Rate } / \mathrm{min}\end{array}$} & \multirow{2}{*}{\multicolumn{2}{|c|}{$\begin{array}{c}\text { Maximum Dose } \\
\text { of Oxprenolol } \\
\text { Tried }\end{array}$}} \\
\hline $\begin{array}{c}\text { Heart } \\
\text { Rate/min } \\
\text { Achieved }\end{array}$ & $\begin{array}{l}\text { No of } \\
\text { Episodes }\end{array}$ & & & & \\
\hline $\begin{array}{r}<90 \\
90-99 \\
100-109 \\
110-119 \\
>119 \\
\end{array}$ & $\begin{array}{r}1 \\
12 \\
7 \\
4 \\
3\end{array}$ & $\begin{array}{l}120 \\
131 \\
128 \\
145 \\
173 \\
\end{array}$ & $\begin{array}{l}52 \\
38 \\
24 \\
33 \\
33 \\
\end{array}$ & $\begin{array}{c}2 \mathrm{mg} \text { bol } \\
* 4 \mathrm{mg} \\
44 \mathrm{mg} \\
4 \mathrm{mg} \\
6 \mathrm{mg}\end{array}$ & 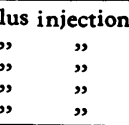 \\
\hline 109 & 27 & 139 & 36 & & \\
\hline
\end{tabular}

*Intravenous infusion of $0.25 \mathrm{mg} / \mathrm{min}$ also tried in some patients in this group.

TABLE II-Response of Other Supraventricular Arrhythmias and Ventricular Arrhythmias to Oxprenolol

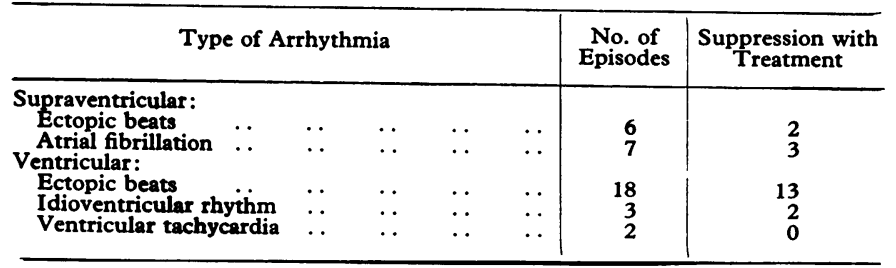

venously also developed ventricular fibrillation preceded by a pronounced fall in blood pressure, but this patient had in fact had several episodes of ventricular fibrillation previously and was in a very unstable myocardial condition when the oxprenolol was given.

Dosage.-The dose used, the method of administration, and the effectiveness in all the episodes of arrhythmia are shown in Table III, in which a satisfactory response in the treatment of supraventricular tachycardia is indicated by a fall in heart rate to below $100 /$ minute. It can be clearly seen that the most effective method is by continuous intravenous infusion, which achieved a total success rate of $69 \%$. The most successful single bolus dose was $6 \mathrm{mg}$ with a $60 \%$ success rate; while $2-\mathrm{mg}$ and $4-\mathrm{mg}$ doses were successful in $25 \%$ or less of the attacks of arrhythmia.

Effect on Blood Pressure.-The hypotensive effect of oxprenolol is shown in Table IV. This occurred in $43 \%$ to TABLE III-Effectiveness of Oxprenolol Related to Dosage and Method of
Administration

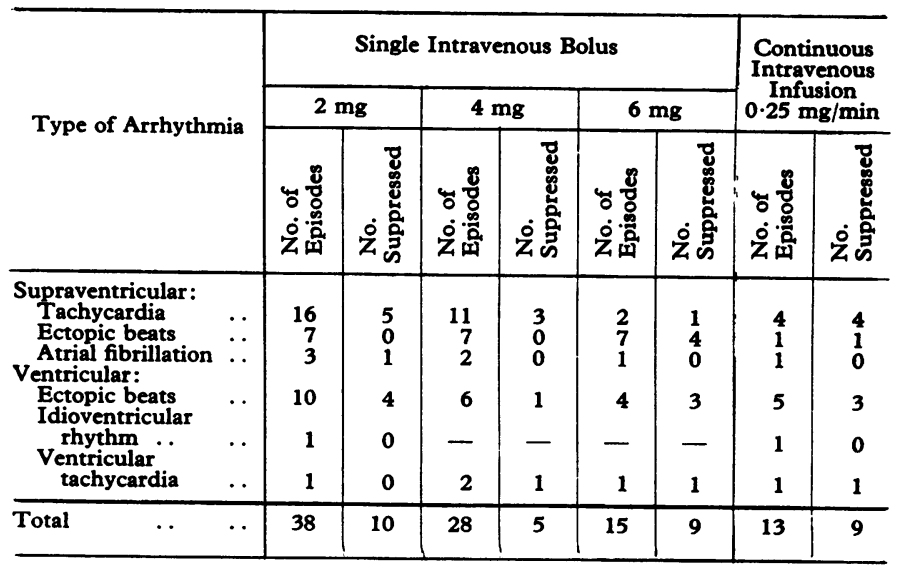

TABLE IV-Effect of Oxprenolol on Blood Pressure

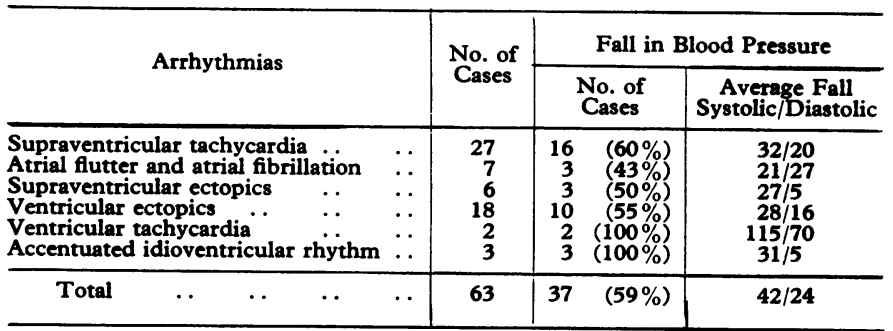

$60 \%$ of the supraventricular arrhythmias and in over half of the episodes of ventricular ectopic beats. The most frequent hypotensive reaction occurred with idioventricular rhythm and ventricular tachycardia, when treatment of all five episodes was associated with a fall in blood pressure, which was serious in the two patients with ventricular tachycardia. Both systolic and diastolic pressures were affected, though the greater fall occurred in systolic pressure $(21$ to $115 \mathrm{~mm} \mathbf{~ H g}$ ) than in diastolic pressure $(5$ to $70 \mathrm{~mm} \mathbf{~ H g}$ ). The relationship between the fall in both systolic and diastolic pressures and the reduction in heart rate produced by oxprenolol in 15 patients with supraventricular tachycardia is shown in the Chart. Though in general the greatest falls in systolic pressure were associated with a corresponding reducation in heart rate, the relationship was not a consistent one. There was even less correlation between the fall in the diastolic pressure and heart rate. The hypotensive effect of oxprenolol did not appear to be related to dosage, developing with 2-mg bolus injections as well as with 6-mg doses and intravenous infusion.

Oral Oxprenolol.-Oral administration-usually in a dose 


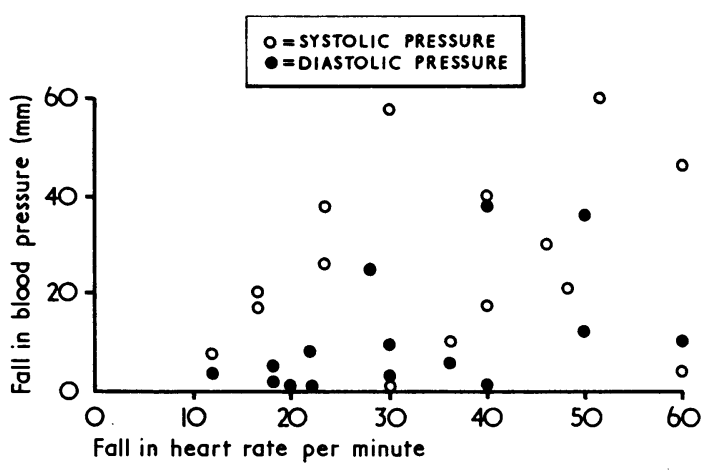

Fall in blood pressure after oxprenolol related to fall in heart rate in patients with supraventricular tachycardia.

of $20 \mathrm{mg}$ four times a day, except in one patient whose dosage was $40 \mathrm{mg}$ four times a day-was tried in 21 patients in whom previous intravenous administration had been effective in suppressing the recurrent arrhythmia. A favourable response was found in both supraventricular and ventricular arrhythmias with a total of $74 \%$ of the episodes suppressed (Table V).

Comparison with Lignocaine.-The effectiveness of oxprenolol after lignocaine has failed, and vice versa, is shown in Table VI. In supraventricular tachycardia the attack was regarded as abolished if the heart rate fell to below $100 /$ minute, while a final heart rate of $100-120 /$ minute was listed as "less severe." Similarly, in this table the response of ectopic beats to treatment was based on their complete abolition or reduction in frequency without abolition ("less severe"). Oxprenolol either abolished or improved the arrhythmia in 9 out of 13 episodes $(69 \%)$ in which lignocaine had previously been ineffective, including both supraventricular tachycardia and ventricular ectopic beats. On the other hand, lignocaine was even more effective when oxprenolol had failed, $80 \%$ of episodes responding to treatment with lignocaine. The main superiority of lignocaine over oxprenolol was in treating ventricular ectopic beats, where seven out of eight oxprenolol-resistant episodes responded to lignocaine.

TABLE v-Effect of Maintenance Treatment with Oral Oxprenolol in Preventing Recurrence of Arrhythmia

\begin{tabular}{|c|c|c|}
\hline Type of Arrhythmia & No. of Episodes Studied & No. of Episodes Suppressed \\
\hline $\begin{array}{l}\text { Supraventricular: } \\
\text { Tachycardia . } \\
\text { Atrial fibrillation } \\
\text { Ectopic beats } . . \\
\text { Ventricular: } \\
\text { Ectopic beats } \\
\text { Idioventricular } \\
\text { Idhythm }\end{array}$ & $\begin{array}{r}13 \\
1 \\
2 \\
6 \\
1\end{array}$ & $\begin{array}{l}9 \\
1 \\
2 \\
4 \\
1\end{array}$ \\
\hline Total & 23 & $17(74 \%)$ \\
\hline
\end{tabular}

TABLE VI-Comparison of Effectiveness of Oxprenolol and Lignocaine

\begin{tabular}{|c|c|c|c|c|c|c|c|c|}
\hline \multirow[b]{2}{*}{ Arrhythmias } & \multicolumn{4}{|c|}{$\begin{array}{l}\text { Effects of Oxprenolol } \\
\text { after Lignocaine had Failed }\end{array}$} & \multicolumn{4}{|c|}{$\begin{array}{l}\text { Effects of Lignocaine } \\
\text { after Oxprenolol had Pailed }\end{array}$} \\
\hline & 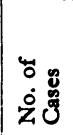 & 之䓵 & 象 & 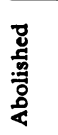 & 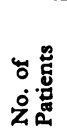 & 吕莺 & 总 & 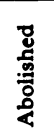 \\
\hline $\begin{array}{l}\begin{array}{l}\text { Supraventricular } \\
\text { tachycardia } \\
\text { Supraventricular } \\
\text { ectopics }\end{array} \\
\begin{array}{l}\text { Atrial flutter- } \\
\text { fibrillation ... }\end{array} \\
\begin{array}{l}\text { Ventricular ectopics } \\
\text { Ventricular }\end{array} \\
\begin{array}{l}\text { tachycardia } \\
\end{array}\end{array}$ & $\begin{array}{l}1 \\
5 \\
1\end{array}$ & - & $\begin{array}{l}2 \\
1 \\
1 \\
-\end{array}$ & $\begin{array}{l}3 \\
- \\
-2 \\
-\end{array}$ & $\begin{array}{r}1 \\
8 \\
-\end{array}$ & $\begin{array}{l}- \\
1 \\
1 \\
-\end{array}$ & $\begin{array}{l}1 \\
1 \\
- \\
-\end{array}$ & $\begin{array}{l}2 \\
\overline{7} \\
-\end{array}$ \\
\hline Total & 13 & 4 & 4 & 5 & 15 & 3 & 2 & 10 \\
\hline
\end{tabular}

\section{Discussion}

Though the mechanism of action of beta-blocking drugs in cardiac arrhythmia has been the subject of controversy, probably both the beta-blocking activity (Williams, 1966) and the quinidine-like suppressive action on the myocardial cell membrane (Sekiya and Williams, 1964; Lucchesi, 1965) play a part. However, the negative inotropic action of this group of drugs, exemplified most extensively by propranolol, may adversely affect cardiac function, leading on occasions to serious heart failure (Stock, 1966; Szekely et al., 1966; Harrison, 1969). This is particularly relevant in the early stages of acute myocardial infarction where the incidence of left ventricular failure may be over $60 \%$ (Lown, 1968). Oxprenolol has been found to be a potent beta-receptor blocker both experimentally (Bender, 1968) and in man (Grandjean and Rivier, 1968), but it differs from propranolol in producing significantly less depression of myocardial contractility in therapeutic doses (Grandjean and Rivier, 1968; Nayler et al., 1969). This is probably due to its intrinsic sympathomimetic activity (Brunner et al., 1968), a property not possessed by propranolol.

The present study has confirmed the effectiveness of oxprenolol in treating ventricular ectopic beats, over $70 \%$ of the episodes being abolished by the drug; in addition it vas effective in all three cases of idioventricular rhythm in which it was tried. A similarly satisfactory response was also obtained with supraventricular tachycardia, almost half the episodes being abolished and another $25 \%$ improved with a fall of atrial rate below 110 /minute. The response to oxprenolol was more disappointing with supraventricular ectopic beats, but this may be attributable to a less pronounced influence of catecholamine release in producing these arrhythmias in the early stages of myocardial infarction compared with ventricular ectopic beats, where catecholamine release is much greater (Jewitt et al., 1969). The most effective mode of administration of oxprenolol is by continuous intravenous infusion in a dose of $0.25 \mathrm{mg} /$ minute up to a total of $30 \mathrm{mg}$, and if a single bolus injection is used then $6 \mathrm{mg}$ is likely to be more effective than 2-mg or 4-mg doses. Oral oxprenolol $20 \mathrm{mg}$ four times a day also appears to be useful in preventing recurrence of both supraventricular tachycardia and ventricular ectopic beats provided previous response to the drug has been shown by intravenous administration. It is of interest that prolonged oral therapy, while producing the negative chronotropic effect expected, is associated with a positive inotropic effect (Wilson et al., 1968).

The most significant side effect of oxprenolol was its hypotensive effect, which occurred in varying degree in over half of the patients investigated, the fall affecting both systolic and diastolic pressure. Though part of this hypotensive action may be attributable to the reduction in heart rate after oxprenolol, the relationship is not a consistent one, suggesting the possibility that the negative inotropic effect of the drug may also be an important factor in causing the fall in blood pressure. Similar hypotensive effects of intravenous oxprenolol have been described in normotensive subjects by Wilson et al. (1968) and in hypertensive patients by Dorph and Binder (1969), and attributed to the reduction of cardiac output rather than to an alteration of peripheral resistance. There did not appear to be any correlation between the hypotensive effect and the dose used in the present study. In most patients with a fall of blood pressure no associated adverse clinical effects were noted, but in two patients with ventricular tachycardia ventricular fibrillation developed after a profound fall in blood pressure. It is therefore advisable to use oxprenolol with caution where blood pressure is already low, and especial care should be taken with ventricular tachycardia. The drug, however, does appear to have a useful place in treating supraventricular tachycardia and ventricular ectopic beats, and may be effective where lignocaine has failed. 
The only other side effect encountered was nausea, which occurred in only one or two patients. No patient showed any evidence of cardiac decompensation as a result of oxprenolol administration. Oxprenolol, therefore, would appear to offer an advantage over propranolol in having less tendency to produce adverse effects on myocardial function. Whereas both propranolol and oxprenolol reduce the heart rate at rest and after exercise, oxprenolol leads to a smaller reduction of cardiac output than propranolol, since the resultant bradycardia with oxprenolol is compensated by a greater increase in stroke volume (Grandjean and Rivier, 1968). The other potential advantage is the less pronounced effect on bronchial muscle, though this aspect was not investigated in the present study. Beumer et al. (1968, 1969) have convincingly shown that oxprenolol produces much less bronchospasm in asthmatic patients than D-propranolol, and in fact it had as little effect on respiratory function as D-propranolol, in which the beta-blocking effect is much less pronounced than in its racemic isomer.

We are indebted to Dr. R. Rondel, of Ciba, for supplies of oxprenolol (Trasicor).

\section{References}

Bath, J. C. J. L. (1966). American fournal of Cardiology, 18, 415. Bender, F. (1968). Medizinische Welt, 2, 2481.
Beumer, H. M. (1968). Medizinische Klinik, 63, 1939.

Beumer, H. M. (1969). Pharmacologia Clinica, 1, 172.

Brunner, H., Hedwall, P. R., and Meier, M. (1968). Arzneimittel-Forschung, $18,164$.

Chamberlain, D. A. (1966). Cardiologia, 49, Suppl. No. 2, p. 27.

Dorph, S., and Binder, C. (1969). Acta Medica Scandinavica, 185, 443.

Epstein, S. E., and Braunwald, E. (1966). New England fournal of Medicine, $275,1106,1175$.

Frieden, J., Enselberg, C. D., Rosenblum, R., and Rosenberg, A. S. (1967). Circulation, 36, Suppl., p. 113

Grandjean, T., and Rivier, J. L. (1968). British Heart fournal, 30, 50.

Harrison, D. C. (1969). Cardiovascular Clinics, 1, 46.

Harrison, D. C., Griffin, J. R., and Fiene, J. T. (1965). New England fournal of Medicine, 273, 410 .

Irons, G. V., Ginn, W. N., and Orgain, E. S. (1967). American fournal of Medicine, 43, 161

Jewitt, D. E.; et al. (1969). Lancet, 1, 635.

own, B. (1968). In Acute Myocardial Infarction, ed. D. G. Julian and M. F. Oliver, p. 171. Edinburgh, Livingstone.

Lucchesi, B. R. (1965). Journal of Pharmacology and Experimental Therapeutics, 148, 94.

McNeill, R. S. (1964). Lancet, 2, 1101.

Nayler, W. G., Chipperfield, D., and Lowe, T. E. (1969). Cardiovascular Research, 3, 30.

Sandler, G., and Clayton, G. A. (1970). British Medical fournal, 2, 399.

Sekiya, A., and Williams, E. M. V. (1964). British fournal of Pharmacology, $21,473$.

Stephen, S. A. (1966). American fournal of Cardiology, 18, 463.

Stock, J. P. P. (1966). American fournal of Cardiology, 18, 444.

Stock, J. P. P., and Dale, N. (1963). British Medical fournal, 2, 1230.

Szekely, P., et al. (1966). American fournal of Cardiology, 18, 426.

Theilen, E. O., and Wilson, W. R. (1968). Medical Clinics of North America, 52, 1017.,

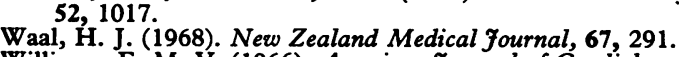

Williams, E. M. V. (1966). American fournal of Cardiology, 18, 399.

Wilson, D. F., Watson, O. F., Peel, J. S., Langley, R. B., and Turner, A. S. (1968). New Zealand Medical fournal, 68, 145.

\title{
Gonococcal Ophthalmia Neonatorum Despite Treatment with Antibacterial Eye-drops
}

\author{
C. B. S. SCHOFIELD, R. A. SHANKS
}

British Medical fournal, 1971, 1, 257-259

\section{Summary}

Over a five-year period, 1964-8, 48 cases of gonococcal ophthalmia neonatorum were notified to the department of venereology in Glasgow. Thirty-seven babies were born in hospital and 11 at home. The conjunctivitis, usually recorded as a "sticky eye," developed between 1 and 13 days of birth, 36 by the fourth day.

Diagnosis by culture of Neisseria gonorrhoeae was delayed in some cases up to $\mathbf{3 0}$ days after the appearance of the signs for those born in hospital and 15 days for those born at home, usually because of the blind use of antibacterial eyedrops which produced temporary alleviation of the signs without eradicating the infection; chloramphenicol was noteworthy in this respect.

A "sticky eye" will resolve without the use of antibacterial agents, ophthalmia neonatorum will not. When it is decided to use an antibacterial agent pretreatment conjunctival smears for immediate staining and swabs for culture should be taken and the case notified to the medical officer of health.

Gonococcal ophthalmia is a preventable disease. In view of the obstetricians' already heavily committed clinical work

Ruchill Hospital, Glasgow N.W.

C. B. S. SCHOFIELD, M.D., F.R.C.P.ED., Consultant Venereologist

Paediatric Department, Royal Maternity Hospital, Glasgow C.4

R. A. SHANKS, M.D., F.R.C.P.(LOND., GLASG.), Physician in charge load there is need for venereologists to collaborate, on consultation and within the maternity hospitals wherever possible, in the screening of antenatal patients for candidiasis and trichomoniasis as well as for gonorrhoea. Some target groups, those with a pathological vaginal discharge or with certain adverse social factors, warrant more thorough investigation, while all those treated require further examination to ensure cure.

\section{Introduction}

Despite the absence of accurate notification it is clear from published statistics that there has been a considerable increase in the incidence of gonorrhoea in most countries of the world (W.H.O., 1969). Certain aspects of this increase make it a matter of concern not only to venereologists but to obstetricians and paediatricians as well.

In England and Wales the incidence of gonorrhoea in 1958 was 22,398 males and 5,489 females, showing the usual male predominance. In 1968 the figures were 32,595 males and 12,367 females (Department of Health and Social Security, 1969). As elsewhere this considerable increase in the incidence of gonorrhoea in females has been seen in Glasgow-187 in 1958, 391 in 1968-the increase being mainly among teenagers and women in their early twenties (Department of Health and Social Security, 1969). It is not surprising, therefore, that gonococcal ophthalmia neonatorum should again make its appearance in a country where prophylactic instillation of eye-drops has been abandoned. In the report from England and Wales the figures for 1968 included 35 